\title{
PENGARUH PERENDAMAN AIR NIRA TERHADAP MUTU MIKROBIOLOGIS DAN ORGANOLEPTIK CAKALANG (Katsuwonus pelamis L) ASAP
}

\author{
Josefa Tety Kaparang, Joyce C.V. Palenewen, Hanny W. Mewengkang \\ Staf Pengajar pada Program Studi Teknologi Hasil Perikanan FPIK UNSRAT Manado.
}

\begin{abstract}
ABSTRAK
Komoditi hasil laut yaitu ikan sifatnya cepat mengalami pembusukan sehingga diperlukan adanya pengolahan dan pengawetan yang termasuk didalamnya pengasapan. Produk pengasapan dalam hal ini cakalang asap merupakan komoditi andalan Sulawesi Utara. Oleh karena itu, mutu dan keamanan produk ini perlu diperkuat dan dijamin melalui pengendalian mutu dan teknik pengolahan yang tepat. Tujuan jangka panjang penelitian ini adalah untuk menciptakan pangan fungsional dari produk olahan ikan cakalang asap yang sehat dan aman. Target khusus penelitian ini adalah untuk mengetahui konsentrasi larutan nira sebagai pengawet dan pewarna alami yang mampu meningkatkan daya awet cakalang asap. Dalam penelitian ini akan digunakan 4 konsentrasi larutan perendaman yaitu konsentrasi 5\% (100 gr kulit kayu dalam $2.000 \mathrm{ml}$ air nira), konsentrasi 10\% (200gr kulit kayu dalam $2.000 \mathrm{ml}$ air nira), konsentrasi 15\% (300 gr kulit kayu dalam $2.000 \mathrm{ml}$ air nira) dan control $0 \%$ (2.000 ml air nira tanpa kulit kayu) dengan lama penyimpanan $(0,3,6$, dan 9 hari) pada suhu ruang dan dilakukan dengan 2 kali ulangan. Metode yang digunakan dalam penelitian ini adalah metode deskriptif eksploratif yang bertujuan untuk menemukan suatu pengetahuan baru yang sebelumnya belum ada dengan membuat deskripsi/gambaran secara sistematis. Variabel yang diamati meliputi: kadar air, $\mathrm{Ph}$, total bakteri, jamur dan uji organoleptik. Hasil pengujian kadar air menunjukkan bahwa kadar air terendah dengan skor 52,41 pada konsentrasi $15 \%$. Ph terendah pada konsentrasi $15 \%$ yaitu 4,63. Total bakteri dengan nilai terendah $2,151 \mathrm{cfu} / \mathrm{g}$ ada pada konsentrasi $15 \%$. Untuk keberadaan Jamur pada konsentrasi $15 \%$ sampai hari ke-3 belum ditemukan. Uji organoleptik yang meliputi bau, rasa dan warna, hasil yang paling baik terdapat pada konsentrasi $15 \%$ dengan skor 8,20. Kesimpulan dari penelitian ini adalah konsentrasi $15 \%$ merupakan konsentrasi yang paling baik untuk yang mampu meningkatkan mutu cakalang asap.
\end{abstract}

Kata kunci: Cakalang Asap, Air Nira, Mikroba.

\section{PENDAHULUAN}

Memasuki tahun ke-3 peluang yang ditawarkan oleh MEA dapat digunakan oleh Indonesia untuk melebarkan perekonomiannya khususnya dalam bidang perikanan mengingat industri kemaritiman Indonesia terhitung sebagai salah satu yang terbesar di ASEAN, sehingga dengan memanfaatkan kekayaan laut diyakini masyarakat Indonesia dapat bersaing dalam komitmen MEA.

Produksi perikanan di Indonesia cukup besar baik untuk perikanan tangkap maupun perikanan budidaya dimana pada Tahun 2017 sebesar 7,8 juta ton meningkat menjadi 9,45 juta ton pada Tahun 2018 (KKP 2018). Sulawesi Utara merupakan salah satu daerah di Indonesia yang banyak menghasilkan ikan cakalang. Hasil perikanan tersebut pada umumnya dikonsumsi dalam bentuk segar, diekspor dan diolah secara modern maupun tradisional.

Ikan cakalang merupakan salah satu produk perikanan yang menjadi andalan
Sulawesi Utara karena memiliki peluang pasar yang sangat luas baik untuk konsumsi lokal maupun untuk diekspor. Selain itu juga cakalang memiliki kandungan protein yang tinggi dan juga memiliki kandungan gizi lain diantaranya: mineral, vitamin dan lemak tak jenuh. Protein ikan sangat diperlukan oleh manusia karena dapat menjadi sumber energi yang sangat dibutuhkan dalam menunjang kehidupan sehari-hari.

Produk cakalang asap Sulawesi Utara sangat diminati oleh masyarakat, dapat dilihat dengan banyaknya permintaan baik oleh wisatawan lokal maupun internasional. Selain untuk dikonsumsi cakalang asap juga dijadikan sebagai souvenir. Komoditi ikan cakalang asap Sulawesi Utara dapat dikatakan sebagai exotic indogenous food tetapi masih diperhadapkan dengan beberapa permasalahan yaitu: produk masih terbatas, pengasapan dilakukan secara konvensional, produk belum dikemas sehingga mudah dihinggapi lalat, mengakibatkan kontaminasi bakteri, menyebabkan produk cepat menjadi busuk dan mudah tengik. Selain 
itu juga penggunaan pengawet dan pewarna sintetis masih menjadi permasalahan yang cukup serius karena dapat menyebabkan produk ini tidak sehat apabila dikonsumsi oleh masyarakat.

\section{METODOLOGI PENELITIAN}

\section{Bahan dan Alat Bahan}

Ikan cakalang (Katsuwonus pelamis L) sebagai sampel, air nira segar dan kulit kayu pohon pamuli sebagai pengawet dan pewarna alami. Sedangkan untuk bahan kimia yang digunakan adalah akuades, $\mathrm{NaCl}$, Nutrient Agar (NA) dan Potato Dextrose Agar (PDA).

\section{Alat \\ Alat-alat yang digunakan adalah pisau untuk memotong ikan, tempat untuk merendam ikan, autoklaf, cawan petri, panic stainless steel, pengaduk, blender, timbangan analitik, tabung reaksi, oven pengering, pipet, lampu spiritus, erlenmeyer, desikator, alumunium foil, rak pengasapan. \\ Prosedur Pembuatan Larutan Nira Prosedur Pembuatan Cakalang Asap Prosedur Analisa $\mathbf{P h}$ Prosedur Analisa Kadar Air Prosedur Analisa Total Bakteri Prosedur Analisa Total Jamur Uji Organoleptik}

\section{HASIL DAN PEMBAHASAN}

\section{Analisa Kadar Air}

Kadar air merupakan banyaknya air yang terkandung dalam bahan yang dinyatakan dalam persen. Kandungan air dalam bahan pangan ikut menentukan kesegaran dan daya awet bahan itu sendiri. Hasil pengujian kadar air selama penyimpanan ditunjukkan oleh tabel di bawah ini:

\begin{tabular}{ccccc}
\hline Konsentrasi & 0 hari & 3 hari & 6 hari & 9 hari \\
\hline $0 \%$ & 53,50 & 55,69 & 58,44 & 59,79 \\
$5 \%$ & 53,48 & 53,51 & 54,90 & 58,10 \\
$10 \%$ & 52,72 & 53,45 & 54,32 & 57,86 \\
$15 \%$ & 52,41 & 53,07 & 54,11 & 56,71 \\
\hline
\end{tabular}

Berdasarkan pemaparan hasil di atas dapat dijelaskan bahwa nilai kadar air yang paling rendah terdapat pada perlakuan dengan konsentrasi $15 \%$. Hal ini kemungkinan disebabkan oleh adanya senyawa-senyawa asam organik berupa asam laktat yang terkandung dalam cakalang asap tersebut lebih tinggi dibanding dengan yang terkandung dalam cakalang asap yang diberi perlakuan 5\%, 10\% bahkan kontrol. Selain itu juga jumlah kandungan asam laktat yang terdapat pada perlakuan $15 \%$ lebih besar sehingga peran yang diberikan dalam menekan peningkatan kadar air dan menghambat pertumbuhan mikroba perusak juga jauh lebih besar. Bora (2010) menyatakan asam laktat mampu menarik air keluar dari dalam daging ikan pada saat pengasapan dan menekan terjadinya peningkatan kadar air dalam daging ikan asap. Menurut Desroiser (1988), jenis pengawet seperti garam, asam dan gula berfungsi sebagai pemberi sedangkan pengawet yang bersifat higroskopik dalam bentuk larutan dan mempunyai tekanan osmotik dapat menyerap air keluar dari bahan dan menekan peningkatan kadar air sehingga dapat menghambat pertumbuhan bakteri yang tidak diinginkan.

\section{Analisa pH}

Uji pH digunakan untuk menyatakan tingkat keasaman atau kebasaan yang dimiliki oleh suatu bahan. $\mathrm{pH}$ kurang dari 7 bersifat asam, $\mathrm{pH}$ lebih dari 7 bersifat basa atau alkali dan $\mathrm{pH}$ sama dengan 7 bersifat netral. Hasil dari pengujian $\mathrm{pH}$ pada cakalang asap dalam penelitian ini dapat dilihat pada tabel berikut:

\begin{tabular}{ccccc}
\hline Konsentrasi & 0 hari & 3 hari & 6 hari & 9 hari \\
\hline $0 \%$ & 4,94 & 4,74 & 6,15 & 7,49 \\
$5 \%$ & 4,76 & 4,73 & 6,60 & 7,22 \\
$10 \%$ & 4,77 & 4,79 & 6,70 & 6,35 \\
$15 \%$ & 4,63 & 4,72 & 4,91 & 5,38 \\
\hline
\end{tabular}

Berdasarkan uraian hasil penelitian di atas dapat dijelaskan bahwa $\mathrm{pH}$ cakalang asap yang diberi perlakuan 5\%, 10\% bahkan kontrol $0 \%$ hanya sampai pada penyimpanan hari ke-3 yang nilainya berada di bawah 5 sedangkan untuk perlakuan $15 \%$ sampai hari keenam nilai pH masih berada di bawah nilai 5. Dengan kata lain perlakuan $15 \%$ memiliki $\mathrm{pH}$ yang paling rendah. Rostini (2007) menyatakan bahwa pH yang rendah 3-5 dapat menghambat kontaminasi mikroorganisme pembusuk, mikroorganisme pathogen serta mikroorganisme penghasil racun.

\section{Total Koloni Bakteri}

Analisa mikroba dalam hal ini TPC digunakan untuk mengetahui jumlah total koloni bakteri yang tumbuh dalam bahan pangan.

Perlakuan 5\%, 10\% dan 15\% ketiganya menggunakan larutan air nira dan kulit kayu 
pamuli tetapi konsentrasinya berbeda sehingga dengan demikian nilai total koloni bakteri yang dihasilkan berbeda pula. Dari ketiga jenis perlakuan yang diuji selama penyimpanan 0-9 hari, menunjukkan bahwa perlakuan dengan konsentrasi $15 \%$ yang lebih baik dibanding perlakuan dengan konsentrasi 5\% dan $10 \%$. Hal ini ditunjukkan dengan total koloni bakteri yang dihasilkan lebih rendah dibanding dengan perlakuan 5\%, 10\% dan kontrol. Pada perlakuan kontrol total koloni bakteri yang dihasilkan paling tinggi karena pada perlakuan tersebut tidak ditambahkan kulit kayu pamuli. Dimana kulit kayu pamuli diduga sebagai pengawet air nira yang dapat mencegah kerusakan nira. Muchtadi, et.al. (2011) bakteri yang terdapat dalam nira adalah bakteri-bakteri dari genus Lactobacillus yang merupakan bakteri yang menguntungkan.

Total koloni bakteri pada cakalang asap dalam penelitian ini dapat kita lihat pada tabel berikut ini:

\begin{tabular}{ccccc}
\hline Konsentrasi & 0 hari & 3 hari & 6 hari & 9 hari \\
\hline $0 \%$ & 2,733 & 2,793 & 4,269 & 4,514 \\
$10 \%$ & 2,389 & 2,793 & 3,045 & 4,412 \\
$15 \%$ & 2,350 & 2,777 & 2,972 & 4,406 \\
$20 \%$ & 2,151 & 2,628 & 2,874 & 4,323 \\
\hline
\end{tabular}

Total Koloni Jamur

Pengujian jamur dilakukan dengan menggunakan media PDA dan bertujuan untuk mengamati ciri-ciri dan jamur yang tumbuh. Total jamur yang dihasilkan pada penelitian ini, dapat kita lihat pada tabel berikut ini:

\begin{tabular}{crrrr}
\hline Konsentrasi & 0 hari & 3 hari & 6 hari & 9 hari \\
\hline $0 \%$ & 0 & 2,889 & 3,958 & 4,129 \\
$5 \%$ & 0 & 2,817 & 3,242 & 3,476 \\
$10 \%$ & 0 & 2,759 & 3,090 & 3,393 \\
$15 \%$ & 0 & 0 & 2,588 & 2,938 \\
\hline
\end{tabular}

Berdasarkan hasil yang diperoleh bahwa pada konsentrasi $0 \%$ jumlah koloni jamur yang dihasilkan paling tinggi. Hal ini kemungkinan disebabkan karena cakalang asap tersebut memiliki kadar air yang lebih sesuai untuk pertumbuhan jamur. Sedangkan pada konsentrasi $15 \%$ jumlah koloni jamur yang dihasilkan paling rendah. Diduga hal ini disebabkan tingginya asam laktat yang dihasilkan sehingga dapat menekan pertumbuhan jamur. Hal lain juga yang menyebabkan rendahnya nilai total koloni jamur, karena pada konsentrasi $15 \%$ terdapat jumlah kulit kayu pamuli yang paling besar. Dimana kulit kayu pamuli tersebut diduga merupakan bahan pengawet nira yang mengandung tannin yang dapat menghambat pertumbuhan jamur. Muchtadi, et.al. (2011) menambahkan bahwa beberapa kulit pohon yang digunakan untuk mengawetkan nira diduga mengandung komponen tannin yang aktif sebagai bahan antimicrobial serta bersifat fungisida. Dari hasil di atas dapat kita simpulkan bahwa perlakuan dengan konsentrasi $15 \%$ dapat dijadikan sebagai pengawet alami pada cakalang asap karena mampu menghambat pertumbuhan jamur sampai pada hari ke-3.

\section{Uji Organoleptik \\ Rasa Cakalang Asap}

Uji Organoleptik ini berhubungan dengan indera pengecap (lidah) yang menyangkut kepekaan rasa yang bertujuan untuk melihat kesan panelis terhadap rasa dari cakalang asap. Tabel organoleptik rasa cakalang asap dapat kita lihat berikut ini:

\begin{tabular}{ccccc}
\hline Konsentrasi & 0 hari & 3 hari & 6 hari & 9 hari \\
\hline $0 \%$ & 4,60 & 3,53 & 3,00 & 3,00 \\
$5 \%$ & 6,20 & 5,00 & 3,93 & 3,27 \\
$10 \%$ & 6,20 & 5,00 & 4,60 & 3,80 \\
$15 \%$ & 8,20 & 7,40 & 6,47 & 4,20 \\
\hline
\end{tabular}

Berdasarkan uraian di atas dapat kita lihat bahwa konsentrasi $15 \%$ memberikan pengaruh yang signifikan terhadap cita rasa cakalang asap, dimana menurut panelis cakalang asap dengan konsentrasi 15\% mempunyai rasa yang manis sedangkan untuk $5 \%$ dan $10 \%$ rasanya agak pahit dan untuk kontrol mempunyai rasa yang pahit. Tingginya kesan panelis terhadap cita rasa cakalang asap dengan konsentrasi 15\% diduga karena mengandung asam laktat yang tinggi yang dapat mempertahankan cita rasa ikan asap. Menurut Amin dan Laksono (2001), rasa cakalang asap dipengaruhi oleh rasa asam laktat.

\section{Bau Cakalang Asap}

Uji Organoleptik ini berhubungan dengan indera pembau (hidung) yang dapat digunakan sebagai indikator terjadinya kerusakan pada produk, misalnya adanya bau busuk. Pada penelitian ini uji organoleptik bau bertujuan untuk melihat kesan panelis terhadap bau dari produk cakalang asap yang dihasilkan. Tabel organoleptik bau cakalang asap dapat kita lihat berikut ini:

\begin{tabular}{ccccc}
\hline Konsentrasi & 0 hari & 3 hari & 6 hari & 9 hari \\
\hline $0 \%$ & 7,13 & 6,20 & 4,10 & 3,53 \\
$5 \%$ & 7,27 & 6,87 & 5,13 & 4,47 \\
$10 \%$ & 7,40 & 7,13 & 5,40 & 4,60 \\
$15 \%$ & 8,20 & 7,80 & 6,60 & 4,87 \\
\hline
\end{tabular}

Berdasarkan hasil di atas dapat kita lihat bahwa semua perlakuan yaitu $0 \%, 5 \%, 10 \%$ dan $15 \%$ pada hari ke-0 nilainya masih di atas 7 
yang merupakan nilai untuk persyaratan mutu dan keamanan pangan ikan asap. Pada hari ke-3 hanya perlakuan $10 \%$ dan $15 \%$ yang masih termasuk dalam syarat mutu ikan asap dengan skor 7,13 dan 7,8. Pada hari ke-9 kesan panelis sangat rendah karena cakalang asap sudah ditumbuhi jamur. Dengan adanya pertumbuhan jamur ini mengakibatkan ikan ini mudah teroksidasi dan menyebabkan bau tengik sementara protein ikan juga terurai dan menghasilkan bau busuk. Amin dan Laksono (2001) menyatakan bahwa bau busuk pada cakalang asap terjadi karena adanya perubahan fisik maupun kimia pada cakalang asap. Perubahan fisik terjadi disebabkan oleh pigmen bakteri yang menghasilkan lendir disertai bau busuk sehingga makanan tidak layak lagi untuk dikonsumsi.

\section{Warna Cakalang Asap}

Uji Organoleptik warna dapat kita lakukan dengan menggunakan indera penglihatan (mata). Tujuan uji organoleptik warna pada penelitian ini untuk melihat tingkat kesukaan panelis terhadap warna cakalang asap yang dihasilkan selama penyimpanan sampai hari ke-9. Tabel organoleptik warna dapat kita lihat berikut ini:

\begin{tabular}{ccccc}
\hline Konsentrasi & 0 hari & 3 hari & 6 hari & 9 hari \\
\hline $0 \%$ & 7,13 & 5,67 & 3,53 & 3,00 \\
$5 \%$ & 7,27 & 6,33 & 4,20 & 3,27 \\
$10 \%$ & 7,53 & 7,13 & 4,47 & 3,40 \\
$15 \%$ & 8,20 & 7,53 & 5,40 & 3,80 \\
\hline
\end{tabular}

Data di atas menunjukkan bahwa pada konsentrasi $0 \%$ panelis masih memberikan kesan suka terhadap warna cakalang asap yaitu dengan skor 7,13 kemudian sudah mulai mengalami penolakan pada hari ke-3 sampai pada hari ke-9. Pada konsentrasi 5\% panelis memberikan kesan suka pada 0 hari dengan nilai 7,27 kemudian mulai mengalami penolakan pada hari ke-3 sampai hari ke-9. Pada konsentrasi $10 \%$ berbeda dengan 2 konsentrasi sebelumnya karena panelis masih memberikan kesan suka sampai hari ke-3. Kesan panelis yang paling tinggi ditunjukkan pada konsentrasi $15 \%$ yaitu 0 hari dengan nilai 8,2 dan hari ke-3 dengan nilai 7,53. Dari hasil di atas dapat kita lihat bahwa cakalang asap yang diberi perlakuan $10 \%$ dan $15 \%$ sampai pada penyimpanan hari ke-3 masih memenuhi nilai organoleptik persyaratan mutu dan keamanan pangan untuk ikan asap. Panelis memberikan kesan tidak suka atau penolakan terhadap warna cakalang asap karena terjadinya pertumbuhan jamur yang mengakibatkan warna pada cakalang asap menjadi putih.

\section{KESIMPULAN DAN SARAN}

\section{Kesimpulan}

Cakalang Asap dengan konsentrasi 15\% menghasilkan warna yang paling baik sehingga dapat dijadikan sebagai pewarna alami.

Secara umum produk cakalang asap dengan konsentrasi $15 \%$ memiliki mutu dan daya awet yang lebih baik karena nilai kadar airnya rendah, nilai $\mathrm{Ph}-$ nya rendah, total koloni bakterinya rendah, total jamur rendah sedangkan uji organoleptik (rasa, bau dan warna) nilainya tinggi.

\section{Saran}

Perlu adanya penelitian lanjutan mengenai bakteri asam laktat pada produk cakalang asap yang direndam dalam air nira dan kulit kayu pamuli.

\section{DAFTAR PUSTAKA}

Afrianti L. H, 2013. Teknologi Pengawetan Pangan. Penerbit Alfabeta, Bandung.

Afrianto E dan E. Liviawaty, 1989. Pengawetan dan Pengolahan Ikan. Penerbit Kanisius, Yogyakarta

Afrianto E., Liviawaty E dan Rostini, 2006. Pemanfaatan Limbah Sayuran Untuk Memproduksi Biomasa Lactobacillus Plantarum Sebagai Bahan Edible Coating Dalam Meningkatkan Masa Simpan Ikan Segar dan Olahan. Laporan Akhir. UNPAD.

Amin dan Leksono, 2001. Analisis Pertumbuhan Mikroba Ikan Jambal Siam (Pangasius sutchi) Asap Yang Telah Diawetkan Secara Ensiling. Jurnal Nasional Indonesia.

Bahar B, 2004. Panduan praktis Memilih dan Menangani Produk Perikanan. Penerbit PT. Gramedia Pustaka Utama, Jakarta.

Bora N, 2010. Penggunaan Beberapa Jenis Ensiling Sebagai Pengawet Alami Untuk Meningkatkan Mutu dan Daya Awet Cakalang (Katsuwonus pelamis L) Asap. Tesis. Pascasarjana UNSRAT, Manado.

Buckle K. A., G.H. Edwards and F. Wooton, 1987. Ilmu Pangan. Penerjemah Hari Purnomo dan Adiono. Universitas Indonesia, Jakarta.

Desroiser W, 1988. Teknologi Pengawetan Pangan. Penerjemah Muchji Muljohardjo. Penerbit Universitas Indonesia, Jakarta.

Dwijoseputro D, 2005. Dasar-Dasar Mikrobiologi. Penerbit Djambatan, Jakarta.

Fardiaz S, 1987. Bahan Kuliah Mikrobiologi Pangan I. Jurusan Teknologi Pangan dan Gizi. Fakultas Teknologi Pertanian. IPB, Bogor.

Fardiaz S, 1992. Petunjuk Laboratorium Mikrobiologi Pengolahan Pangan. Pusat Antar Universitas Pangan dan Gizi, IPB, Bogor. 
Hidayat N, Padaga M. C dan Suhartini S, 2006 Mikrobiologi Industri. Penerbit ANDI, Yogyakarta.

Ijong F. G, 1996. Study of Bakasang Traditional Fish Sauce From Indonesia. Doctoral Thesis. Hirishima University. Japan.

Ijong F. G, 2002. Mikrobiologi Dasar. Bahan Ajar. Laboratorium Mikrobiologi Hasil Perikanan Jurusan PHP. Fakultas Perikanan dan Ilmu Kelautan. UNSRAT, Manado.

KKP, 2018. Produksi Perikanan di Indonesia.

Lay B. W, 1994. Analisa Mikroba di Laboratorium. PT Raja Grafindo Persada, Jakarta.

Makfoeld D, 1993. Mikotoksin Pangan. Pusat Antar Universitas Pangan dan Gizi. Universitas Gadjah Mada, Yogyakarta.

Rahayu W. P., S. Ma'oen., Suliantary dan S. fardiaz, 1992. Teknologi Fermentasi Produk Perikanan. Pusat Antar Universitas Pangan dan Gizi. IPB, Bogor.
Riadi L, 2013. Teknologi Fermentasi. Edisi 2. Penerbit Graha Ilmu, Yogyakarta.

Rostini I. S, 2007. Peranan Bakteri Asam Laktat (Lactobaccillus Plantarum) Terhadap Masa Simpan Filet merah Pada Suhu Rendah. Fakultas Perikanan dan Ilmu Kelautan. Universitas Padjajaran.

Soekarto, 1982. Penilaian Organoleptik Untuk Industri Pangan dan Hasil ertanian. IPB, Bogor.

Sudarmadji S, 1989. Mikrobiologi Pangan. Penerbit Proyek Pengembangan Pusat Fasilitas Bersama antar Universitas. Universitas Gadjah Mada, Yogyakarta.

Suriawira H. U, 2005. Mikrobiologi Dasar. Penerbit Papas Sinar Sinanti, Yogyakarta.

Winarno F. G, 1992. Kimia Pangan dan Gizi. Penerbit PT Gramedia Pustaka Utama, Jakarta. 